\title{
Water-saving Technology of Rice Irrigation on Kazakstan Rice Systems
}

\author{
Abikenova Saltanat, YespolovTlektes, Aleksey Rau, \\ KalybekovaYessenkul and ZhanashevIssabek
}

Kazakh National Agrarian University, Republic of Kazakhstan, 050000, Almaty, av/Abai, 8

DOI: http://dx.doi.org/10.13005/bbra/1924

(Received: 17 July 2015; accepted: 20 September 2015)

\begin{abstract}
Rice cultivation was developed extensively in Kazakhstan in the 70-90s of the last century. More than 220 thousand hectares of rice irrigation systems were built in the basins of the Syr Darya, the Ili and Karatal Rivers. In the 90s the area of rice crops in the Kyzylorda region, in the basin of the Syr Darya River amounted to 110.0 thous. ha, in the Almaty region, in the basins of the Ili and Karatal Rivers - 26 thous. ha. Operating experience of rice irrigation systems shows that for rice irrigation systems, water withdrawal from irrigation sources of the Syr Darya, Ili, Karatal Rivers is determined by their water content, water consumption of grown crops in the river basins varies widely from 15 to 35 thous. $\mathrm{m}^{3} / \mathrm{ha}$. At the same time, it is established that plants use around 40 $45 \%$ of water, taken from the irrigation sources. The rest goes to technological losses (surface discharges, seepage from channels, losses occurring during transportation of water from irrigation sources to plants). Low efficiency of water use causes water users to increase the volume of water intake by $30 \%$, it results in a reduction of irrigation capabilities of irrigation sources and the area of irrigated land.
\end{abstract}

Keywords.Rice irrigation systems, the Syr Darya River, saline land, experimental plot, water balance, shortened flooding, permanent flooding, rice paddies, drainage network, irrigation rate, water mineralization, groundwater, water balance.

Rice systems of Kazakhstan, initially focused on "hard" control of the natural environment and water resources, achieved significant growth in the agricultural production at the initial stage. Then the increase in output has stabilized at a certain level, after which there was a decline of biological soil productivity and economic productivity of rice systems. In recent years, more than $20 \%$ of engineering rice systems have been withdrawn from agriculture due to secondary salinity and lack of water supply ${ }^{3}$.

\footnotetext{
* To whom all correspondence should be addressed.
}

Experience of rice sowing farms clearly shows that it is possible to obtain high and stable yields of rice on saline lands with the appropriate technology of cultivation and drainage. The ability of rice to grow on saline lands is confirmed by the practice of rice cultivation both in our country and abroad. High yields are obtained in French Guiana, where rice is grown on heavy alluvial clay soils, containing large amounts of sodium and magnesium. Rice cultivation on unfavourable reclamation lands is well developed in India, Japan, France, Pakistan, China, Italy, Hungary and other countries $^{4-7}$.

In India rice is cultivated on the soil in which the sodium bicarbonate content exceeds $0.2 \%$, sodium chloride $-0.4 \%$ and sodium sulfate$0.8 \%$. There are Indian varieties that are the hardiest 
to salinity: SadamondaNo. 55-308, KhokhlaNo. 55940 and BahraNo. 54-15-5. They can be grown in soils with a total salt content of $0.5-4.5 \%$. In France, rice crop cultivation with flooding allowed reclaiming the saline lands in the Camergieriver delta. In Egypt, cotton plant is cultivated after periodical flushing of saline soils using the rice culture ${ }^{8-10}$.

In Pakistan, rice had been cultivated on saline soils for 3 years in a row. More than 100 thous.ha had been introduced into agriculture for the last 15 years. But due to high standing of groundwater and the lack of drainage, the reclamation condition of land was degraded on about the same area of adjacent territory ${ }^{11}$. At the same time, as a result of washing, followed by rice cultivation on the background of deep horizontal drainage, highly saline soils of the Nile delta had been successfully reclaimed and transformed into blossoming oases.

On the farm of the Indian Agricultural Institute in New Delhi, experiments on soil desalinization had been conducted for four years. Desalinization was carried out by continuouscovering of the soil surface with plants (crop rotation: rice-wheat or barley-pea). With this rotation the rice yield amounted to 1.57-1.78 t/ha. Permanent covering of the soil surface with plants helped reducing the accumulation of salts in the soil in the areas with high standing of groundwater level. In the context of the Andhra Pradesh state (India), soil washing of the top most saline soil layer is recommended before rice sowing ${ }^{12}$.

In Japan, preliminary flooding of soil is carried out before rice sowing, Rice is sown only if the $0-10 \mathrm{~cm}$ layer of soil is desalinated sufficiently. In Romania it is recommended to continuously cultivate rice for 5 years in order to desalinate deeper soil horizons. In Hungary, the problem of land desalinization was solved by introducing the so-called grass and pond soil rotation, the fields are used as ponds for 3 years, and then for 2 years they are under crops of alfalfa and 3 years under crops of rice. The result is better fertility of saline soils. The following yield is obtained from each hectareof such plots: rice 3.5-4.0 tonnes, alfalfa hay - 200 tonnes, fish from ponds - up to 0.7 tonnes ${ }^{14-16}$.

It is worth mentioning that rice irrigation systems of the lower reaches of the Syr Darya, Ili,
Karatal Rivers are located on riverine levees and river terraces. Lands of river terraces have different drainage and water conductivity, soils have different humus content, nutrients, mechanical composition and salinity. All of this gave rise to 23 times bigger diversity in crop yields within one irrigation system.

During land reclamation of the floodplaindeltaic landscape of river basins, the balance of natural processes, historical soil balance is disrupted, many properties change (volume weight, filtration characteristics), all of it is mostly of degrading nature. And considering that during rice watering there is a rise of groundwater level with a high mineralization of 8-10 g/l, and the efficiency of the drainage is very low, secondary salinization is observed inside the rice system, especially in lower areas ${ }^{17-19}$.

\section{Methodology}

The object of research is the Akdalinskaya rice irrigation system of the Ile river basin in the Almaty region, where rice production is linked to the shortage of water resources, an increase in agricultural water use and the reduction of water availability of irrigated land. In these circumstances, further irrigation development should follow the following path: save irrigation water, improve quality of the irrigation technology of agricultural crops.

The Akdalinskaya rice system is located in the middle and lower reaches of the Ile River and is one of the most promising areas of rice sowing in Kazakhstan. Currently, about 31 thousand hectares of land is reclaimed here, but in the long term 43.4 thous. hectares can be reclaimed for rice crop rotations. Soil-reclamation conditions of the Akdalinskay rice system are very favourable for the cultivation of rice, fodder, vegetables, melons and gourds.

The methodology of the work envisaged the following: during water supply and maintenance of the layer in rice paddies, measure the flow rate of water supplied to rice (the area from 1.3 to 2.5 hectares, evened out to $\pm 5 \mathrm{~cm}$ ) paddies by trapezoidal weirs; evaporation, transpiration and filtration of water from rice fields by the SHU-3000 vegetation vessels.Monitor decrease in the water level in rice paddies - by depth gauges, with closed water outlets, by the following scheme. With the water layer on a rice 
plot amounting from 10 to $15 \mathrm{~cm}$, observations are carried out for 3 days, decrease in the water level is monitored.

With an average daily decrease in the water level in paddies up to $20 \mathrm{~mm}$ or more, from which evaporation and transpiration amounts to $10 \mathrm{~mm}$ per day, water filtration into soil $-10 \mathrm{~mm}$ per day or more, the discharge of water from a rice paddy is not carried out, filtration provides water exchange in a paddy and removal of salts and harmful compounds from the soil root zone into groundwater and drainage channels. Water circulation andwater discharge in such paddies are not carried out during the whole irrigation period.

In the paddies where the daily decrease in the water level is below $20 \mathrm{~mm}$, water mineralization in rice paddies is monitored; when the permissible limit of water mineralization of 2.5 $\mathrm{g} / \mathrm{l}$ in a paddy is reached, water in paddies is changed. During water change, water outlets from the irrigation channel to rice paddies are closed, and the outlets from a paddy to drainage channels are opened. After a full discharge of water, the outlets from paddies to drainage channels are closed, the outlets from the irrigation channel into the rice paddy are opened, the paddy gets flooded and the water level is maintained at $10-15 \mathrm{~cm}$. Water circulation in paddies is not allowed.

In a production environment, water drainage in rice paddies is envisaged. The drainage amounts to $20 \%$ of the water supply. It is intended to improve water exchange and reduce mineralization of the water layer in rice paddies. Unreasonable technological discharge from paddy fields overstate the irrigation norm of rice by 5-6 thousand $\mathrm{m}^{3} /$ ha (Table 1 ).

Large water losses in the irrigation network and excessive irrigation norms form the unnecessary discharge of water into the drainage network and lead to an excessiveflow rate of irrigation water. Therefore, the study and introduction of the water-saving irrigation technology of rice, leading culture in Akdalinskaya rice system, is very relevant and addresses issues of water conservation, improvement of social, environmental and economic issues in the region.

Rice irrigation modes are used in a production environment in the Akdalinskaya rice system: permanent and shortened flooding; at the same time, unreasonable discharges of water from rice paddies are permitted, up to $20 \%$ of the water supply. As a result of drainage, waste drain through the collector-drainage network amounts to $44 \%$ from the water intake, and the efficiency of irrigation water use in rice field amounts to $0.64-0.75$. Up to $36 \%$ of water, taken from the Ile River for rice irrigation, is discharged into the collector-drainage network.

\section{RESULTS}

On the third plot of the agro-plot of the sixth field of the "Birlik" agro firm in 2012-2014, the water-saving technology of rice irrigation for the "Emerald" variety is studied, taking into account natural and artificial drainage of paddy fields and the amount of water filtration during the period of layer maintenance. The rice irrigation mode on experimental production plots was the following: shortened flooding, i.e. intermittent flooding is carried out during the germination period, but permanent flooding - after the germination is complete. Decrease in the water layer in rice paddies occurs when the water supply is stopped and the layer decreases naturally.

The efficiency of the rice irrigation mode is determined by the flow rate of water for rice irrigation, as well as the yield and costs for its cultivation. At the same time, the basis for the rice irrigation mode is the formation conditions for the optimal salt, nutritional modes of soils and the oxygen and temperature mode of a water layer in a rice field that form high productivity of rice fields.

The research has shown the effect of water filtration in rice fields on the yield and the value of the irrigation norm.

It is established that the amount of filtration water from rice fields during the irrigation period varies. The maximum value of $30 \mathrm{~mm} / \mathrm{day}$ is noted during the initial flooding of rice paddies. Then, as the groundwater level rises, water filtration in rice fields is reduced, and at the end of the irrigation period amounts up to $14.3 \mathrm{~mm} /$ day (Fig. 1).

In the Akdalinskaya rice system, rice fields with the filtration greater than $10 \mathrm{~mm} /$ day amount to more than $70 \%$ of the total irrigated area (Fig. 2). With water filtration in rice fields in a volume of 10 $\mathrm{mm} /$ day, refreshing of water in rice fields occurs due to filtration drains, harmful salts and trace 
elements are removed from the root zone of the rice plant, favourable conditions for water, salt, nutrients and oxygen regimes are created in the rizosphere of rice fields. High trice yield $(60-70 \mathrm{cwt} /$ ha) is formed without water circulation and water discharge.

Fertilizers, improves the temperature mode of the water later and increases the rice yield by $15-18 \%$ (Fig. 3 ).

In paddies with the increased filtration of $20 \mathrm{~mm} /$ day and more, not only salts, but also nutrients are removed from the soil layer into ground water, it leads to lower yields of rice in such rice paddies in the rice system, $20 \%$ the irrigated area. In order to increase the rice yield in these paddies to $50 \mathrm{cwt} / \mathrm{ha}$ and more, it is necessary to additionally introduce mineral fertilizers, 30\% from the recommended rate.

In low paddies, where the day value of filtration is less than $100 \mathrm{~mm} /$ day, it is necessary to monitor water mineralization in rice paddies, as due to salt diffusion from soil groundwater, water mineralization increases and may exceed the permissible limit of $2.5 \mathrm{~g} / \mathrm{l}$. Reduction processes dominate in such paddies, ferrous forms of iron appear and hydrogen sulphide is produced in the soil rhizosphere. That is why, when the critical water mineralization occurs ( $2.5 \mathrm{~g} / \mathrm{l})$ during the vegetation period, it is necessary to fully discharge water and flood rice with fresh water from the irrigation channelin such paddies. Depending on soil salinity and salts diffusion, the number of water changes in the rice paddy during the vegetation period may amount to 2 or more.

The volume of water, supplied to rice paddies, was measured by trapezoidal weirs, installed before flooding. The irrigation norm is determined by the volume of water supply, the norm changes from $16,669 \mathrm{~m}^{3} /$ hatî $28,542 \mathrm{~m}^{3} / \mathrm{ha}$.

The average value of the irrigation norm in rice paddies, determined by weirs, amounts to $19,522 \mathrm{~m}^{3} / \mathrm{ha}, 20,794 \mathrm{~m}^{3} / \mathrm{ha}$ - by vegetation vessels.

Flow rates of irrigation water on one hundredweight of the rice yield amount to 313-332

Table 1. The volume of water supply to the Akdalinskaya rice system

\begin{tabular}{lccccc}
\hline Period & May & June & July & August & $\begin{array}{c}\text { During irrigation } \\
\text { period }\end{array}$ \\
& & & & & 56,841 \\
\hline Volume of water supply to a rice system, $\mathrm{m}^{3} / \mathrm{ha}$ & 13,209 & 16,178 & 15,431 & 12,023 & 5.35 \\
Hydronic module, l/ha & 4.93 & 6.24 & 5.76 & 4.49 & 0.82 \\
Efficiency of inter-farm network & 0.81 & 0.83 & 0.81 & 0.83 & 0.63 \\
Efficiency of farm network & 0.63 & 0.63 & 0.63 & 0.63 & 0.515 \\
Efficiency of the irrigation system & 0.51 & 0.52 & 0.51 & 0.52 & 29,273 \\
Volume of water supply to a rice field, $\mathrm{m}^{3} / \mathrm{ha}$ & 63,761 & 8,413 & 7,870 & 6,252 & 2.75 \\
Hydronic module, l/sec ha & 2.38 & 3.24 & 2.94 & 2.33 & \\
\hline
\end{tabular}

Table 2. The constituents of the rice irrigation norm, adopted by the data of vegetation vessels and flow rates of irrigation water on one hundredweight of rice yield

\begin{tabular}{lcccccc}
\hline $\begin{array}{l}\text { Volume of soil } \\
\text { saturation, } \\
\text { calculated, } \mathrm{m}^{3} / \mathrm{hà} \\
1\end{array}$ & $\begin{array}{c}\text { Filtration } \\
\mathrm{m}^{3} / \mathrm{ha}\end{array}$ & $\begin{array}{c}\text { Evaporation- } \\
\text { transpiration, } \\
\mathrm{m}^{3} / \mathrm{hà} \\
3\end{array}$ & $\begin{array}{c}\text { Waste } \\
\mathrm{drain}, \\
\mathrm{m}^{3} / \mathrm{ha} \\
4\end{array}$ & $\begin{array}{c}\text { Irrigation } \\
\text { norm, } \\
\mathrm{m}^{3} / \mathrm{ha} \\
5\end{array}$ & $\begin{array}{c}\text { Rice yield, } \\
\mathrm{cwt} / \mathrm{ha}\end{array}$ & $\begin{array}{c}\text { Flow rate of } \\
\text { irrigation } \\
\text { water, } \mathrm{m}^{3} / \mathrm{cwt}\end{array}$ \\
\hline 1,280 & 13,600 & 9,800 & - & 24,680 & 57.6 & 428.47 \\
1,280 & 12,000 & 9,800 & - & 23,080 & 59.8 & 385.95 \\
1,280 & 9,600 & 9,800 & - & 20,680 & 64.1 & 322.62 \\
1,280 & 9,600 & 9,800 & - & 20,680 & 65.9 & 313.81 \\
1,280 & 9,600 & 9,800 & - & 20,680 & 64.7 & 319.63 \\
1,280 & 8,000 & 9,800 & - & 19,080 & 62.2 & 306.2 \\
Average, 1,280 & 9,600 & 9,800 & - & 16,680 & 56.5 & 295.22 \\
\hline
\end{tabular}


$\mathrm{m}^{3}$ /cwt, with water filtration in rice paddies for the irrigation period $-9600 \mathrm{~m}^{3} / \mathrm{ha}$. With this volume of filtration, the rice yield amounts to 64.1-65.9 cwt/ ha (Table 2).

On experimental production plot of the "Birlik" agrofirm, where rice was cultivated without discharge and water circulation, the average irrigation norm amounted to 20,158 $\mathrm{m}^{3} / \mathrm{ha}$; including: soil saturation - 1,280 $\mathrm{m}^{3} /$ ha, filtration drain - 9,714 $\mathrm{m}^{3} /$ ha, evaporation-transpiration - 9,800 $\mathrm{m}^{3} / \mathrm{ha}$, rice yield - 65.9 cwt/ha. For production crops of economic subjects (farms), the irrigation norm of

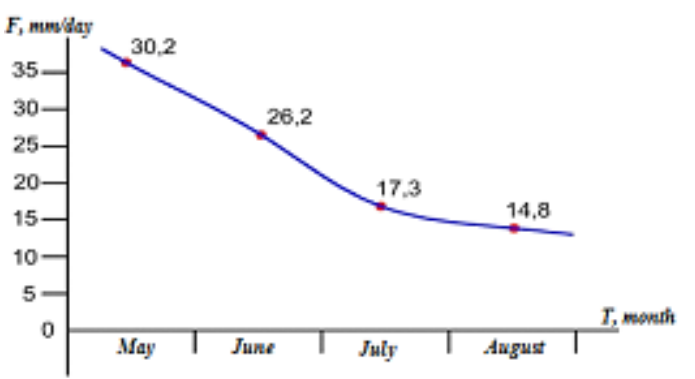

Fig. 1. Filtration schedule on a rice filed during the irrigation period

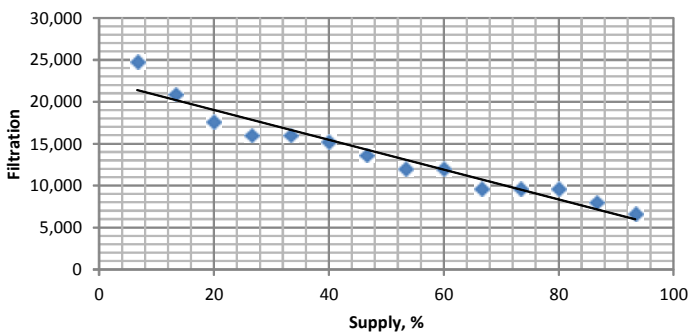

Fig. 2. Empirical curve of the filtration drain supply Supply of filtration drain $\mathrm{P}_{10 \mathrm{~mm} / \mathrm{day}}=72 \%$.

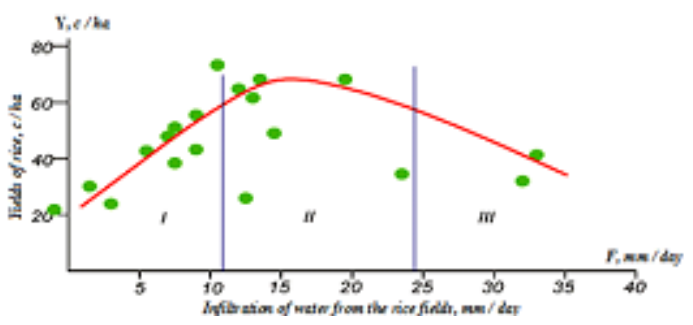

the I zone of insufficient filtration, water change in these paddies is required with an increase of water mineralization of $2.5 \mathrm{~g} / \mathrm{l}$; the II zone of optimal filtration, water circulation and water discharge are not carried out throughout the whole irrigation period; the III zone of increased filtration, extra mineral fertilizers are required.

Fig. 3. Dependence of the rice yield (Y) from the water flow rate on water filtration from rice paddies (W): rice (netto) amounts to $29,273 \mathrm{~m}^{3} /$ ha, rice yield $48.0 \mathrm{cwt} / \mathrm{ha}$.

It is possible to reduce unproductive surface discharge from rice field by $70 \%$ or by 5166 $\mathrm{m}^{3} / \mathrm{h} \alpha$, on $70 \%$ of irrigated area, water filtration in rice paddies is higher than $9 \mathrm{~mm} /$ day. In these paddies water exchange occurs due to a filtration drain, with which harmful salts and microelements are removed to groundwater and the collectordrainage network. It is not recommended to carry out surface discharge in these paddies.

If the recommended water saving technology of rice irrigation in a production environment is followed, the rice irrigation norm will reduce by $5,166 \mathrm{~m}^{3} /$ ha or $29 \%$, and the rice yield will increase by 15-20\%.

\section{DISCUSSION}

a) Experiments aimed at studying the rice productivity on saline soils were carried out on highly saline soils (salt marshes), with the salt content in the arable layer of $1.390 \div 2.313 \%$ by solid residue, the salinity type is sulphate-chloride-sodium. Soils are heavy loam with the volume weight not more than $1.5 \mathrm{~g} / \tilde{\mathrm{nm}}{ }^{3}$ and a specific weight of $2.76 \div 2.80 \mathrm{~g} / \tilde{\mathrm{nm}}^{3}$. The filtration coefficient of soils is low, less than $0.2 \mathrm{~m} /$ day. The soils are favourable for rice cultivation.

b) Water flow rate on one hundredweight of rice crops in the irrigation period amounted to $29,860 \mathrm{~m}^{3} /$ ha- on production crops, 26,060 $\mathrm{m}^{3} / \mathrm{ha}-$ on studied variants of the rice irrigation mode with permanent flooding with water change in a rice paddy, 25,080 $\mathrm{m}^{3} / \mathrm{ha}-$ without water change; $26,870 \mathrm{~m}^{3} / \mathrm{ha}-$ with shortened flooding with water change in the germination period of rice plants, 25,870 $\mathrm{m}^{3} /$ ha - without water change. The data shows a possible reduction of water resources for rice cultivation on saline soils up to $20 \%$ without a decrease in yield.

Large volume of water supply on rice crops in a production environment is caused by unreasonable water discharge from rice paddies, which overflow the drainage channels, reducing its ameliorative effect, which causes a higher level of groundwater and secondary salinization of rice system 
soils.

c) With the seeding rate of $750 \mathrm{pcs} / \mathrm{m}^{2}$, seed germination is good, plant density of rice plants in the phase of full shoots is $89 \div 147$ $\mathrm{pcs} / \mathrm{m}^{2}$. With the variant of permanent and shortened flooding with a water change in a rice paddy in the germination period, the plant density is 4-6\% higher in comparison with the variants of rice irrigation without a water change.

d) Water mineralization changes from $1.026 \mathrm{~g} /$ $\mathrm{l}$ to $1.283 \mathrm{~g} / \mathrm{l}$ and depends from the rice irrigation mode. With the variant of rice irrigation mode with a water changes in the period of full shoots, water mineralization in rice paddies equals to $1.026 \div 1.042 \mathrm{~g} / \mathrm{l}$, with the variant without a water change it amounts to $1.18 \mathrm{~g} / \mathrm{l}$ - for permanent flooding, $1.283 \mathrm{~g} / \mathrm{l}$ - for shortened one. The water salinity type of rice paddies is sulfatechloride-sodium. Mineralization of the irrigation water equals to $1.037 \mathrm{~g} / \mathrm{l}$, drainage water - 2.32-3.26 g/l.

e) the smallest water flow rate on one hundredweight of rice - $439 \mathrm{~m}^{3}$ - are obtained in the variant with permanent flooding with water change in the period of full shoots. The water flow rate on hundredweight of rice seeds shows that it is probably possible to reduce water resources for rice cultivation on saline lands by $15-20 \%$ without a decrease in yield and improved efficiency of rice cultivation.

\section{CONCLUSIONS}

The effective use of land and water resources in rice irrigation systems of Kazakhstan can be achieved only as a result of the introduction of the water saving technology of rice irrigation, effective operation of a drainage waste system and irrigators that water rice, taking into account the water filtration value from rice paddies, which is determined by depth gauges, installed in each rice paddy. In the course of the studies, it is established that water filtration in rice paddies is 10 times more effective than water circulation and surface water discharge, with the water filtration in rice paddies,amounting to $10 \mathrm{~mm} /$ day or $100 \mathrm{~m}^{3} / \mathrm{ha}$ /day, ferrous forms of harmful compounds are drained into groundwater through the filtration drain from the soil surface layer. The water, nutrient and oxygen soil regimes improve. In rice systems of Kazakhstan in almost 70\% of irrigated land, filtration is higher than $10 \mathrm{~mm} /$ day and conducting water discharge from this area is very wasteful. Water dischargein these soils are not to be done throughout the whole irrigation period. To improve soil productivity of rice systems it is necessary to increase their drainage by improving horizontal drainage operation and cleaning the drainagewaste network from silting and overgrowing once in 5 years.

\section{REFERENCES}

1. Umirzakov, S.I., Problems of the rational use of water resources and wastewater recycling. Journal of Agricultural Science, 2009; 12: 3134.

2. Amirgaliev, N.A., Aral-Syrdarinsky basin hydrochemistry, problems of water toxicology. Almaty:Bastau, 2007.

3. Shumakov, B.A., \&Kosov, G.F., Salt regime of the salt marshes complex under rice in the flood plain of the Don River.Reports of the Academy of Agricultural Sciences, 1967; 6: 38-41.

4. Grist, D., In A.P. Giulio et al. (Eds.), Rice (Trans. from English). Moscow: Foreign literature, 1959.

5. Voropaev, G.V., \&Niyazov, B.S., Irrigation in some countries of the world. Almaty: Kaynar, 1970.

6. Volkov, A.I., The soils of southern Kazakhstan and Central Asia, used for rice crops.The compilation: Nature of rice fields soils 1969; 40-67. Almaty: Nauka.

7. Pezenski, S.R., Gas exchange response of typelo-gum (Nyssa aggualica L.) to flooding and salinity.Photosynthetica, 1987; 4(21): 489-493.

8. Tretyakova, G.I., Aleshin, E.P., Satalkina, G.I., \&Aleshin, N.E., Diagnostics of rice salt tolerance.Physiological basis of rice salt tolerance and ways to increase it, Kub.AI, 1988; 288(316): 17-24.

9. Kilamura Kinihiko., Nogyodobokugakkaironbunshu. Frans.Jap.Soc. Jrrig., Drain and Reelam. Eng. 1993; 163: 2933.

10. Yasin Ashraf, M., \&Yousaf, A., Effect of salinity on growth, chlorophyll content and flag leaf area of rice (O. sativa L.) genotypes.IRRN, 1998; 2(23): 33-34.

11. Andryushin, M.A., Rice irrigation. Moscow: Kolos, 1977. 
12. Ovsyannikov, A.S., Influence of mineralized salts on the salt regime of soilsunder the rice crop. The problem of desert reclamation, 1968; 1: 59-64.

13. Shaposhnikov, D.G., Khimich, D.P., \&Bury, A.V. Design features of rice irrigation systems on saline and bottom land. Gand Ì, 1969; 10: 4853.

14. Chose, R.L.M., Ghatge, M.B., Subrahmanyan, V., Rise in India. Indian council of agricultural research, New Delhi, Part I 1956; 43-60.

15. Norman, T., \&Waldron, Z.J., Salinity, photosynthesis and leaf growth.Calif Afr., 1984; 10(38): 38-39.

16. Beecher, H.G., Effect of saline water on rise and soil properties in the Murrumbidgee Valley. Austral.J. Exp. Agr., 1991; 6(31): 819.
17. Sharma Prabpat, K., \&Hall David, O.H.J. Changes in carotenoid composition and photosynthesis in sorghum under high light and salt stresses.Plant Physiol., 1992; 6(140): 661666.

18. Asch, F.,Dingkuhn, M., \&Dorffling, K., Salinity increases $\mathrm{CO} 2$ assimilation but reduce growth in field-grown irrigated rice.Plant and Soil, 2000; 218: $1-10$.

19. Asch, F., \&Wopereis, M.S.C., Responses of field-grown irrigated rice cultivars to varying levels of floodwater salinity under semi-arid conditions.Field Crops Research, 2001; 70: 127137.

20. Koskor, D.R., Growth of a rice at different salt concentration in media a reflection on potential difference between root and shoot.J. Indian Soc. Soil Sci., 1991; 1(39): 94-98. 